\title{
Narrating 'finances' after John Law: Complicity, critique, and the bonds of obligation in Duclos and Mouhy
}

\author{
Julia L. Abramson \\ University of Oklahoma, USA
}

\begin{abstract}
Attending to the peculiar significance of finance(s) and the financier in Old Regime France, this article analyzes narratives that rehabilitate both, circa 1740-1755, in their political, social and biographical contexts. Positive representations are not thought to have been common. Yet following the Law debacle, restoration of traditional court finance resulted in effective administrative practices, universalizing policies and opportunities for merit, combined with money, to drive advancement, competing with hereditary privilege. Across genres, Charles Pinot-Duclos and Charles de Fieux, the Chevalier de Mouhy, depicted how upstart elites enact virtue, philanthropy and patriotism through finance. Their depictions reflected State policies and served common interests of writers and their protectors and patrons. Yet by emphasizing tensions in mid-century society, their texts also challenged readers to reflect critically on relations among finance, politics, society and indebtedness, anticipating a later focus on political economy as such. For today's readers grappling with dilemmas of modern finance, society and obligation, they provide provocative precedents.
\end{abstract}

\section{Keywords}

France, finances, tax farm, patronage, obligation, Duclos, Mouhy

\section{Introduction}

For two centuries, the French term finances evoked an iron bond between, on the one hand, practices such as capital investment and tax collection, and, on the other hand, the State and monarch. The conjoined associations reflect the peculiar role of financiers in seventeenth- and eighteenth-century France. At this time, their role as public agents in royal finances depended on their capacity as investors in and lenders to the debtor State. Within this temporal window, the period spanning the re-incorporation, after the Law debacle, of the Royal General Tax Farms in 1726, to funding crises and military defeat during the Seven Years War (1756-1763), 
saw the apotheosis of traditional Old Regime financial practices and elites under Louis XV. Due to the practice of selling offices and contracting public functions, including excise tax collection, the State was "heavily mortgaged to the financiers" (Murphy, 2005: 231). Finances were paramount in this "kingdom of taxpayers", where nearly everyone had a relationship to a financial officer (Kwass, 2000: 62-115; see also Parsons, 2014: 62).

Surprisingly, although financial structures penetrated nearly every aspect of the polity and society, their literary apologies have received little considered attention. The century is better known for 'anti-financier' expression, whether cartoons, plays or treatises. To be sure, historians note that positive representations of financiers signal their rehabilitation and social integration. Nonetheless, writings praising finance deserve greater attention. For one thing, they reflect characteristic aspects of the society in which finance and politics melded closely (Kaiser, 1991: 1 Note 3; Bosher, 1970; Bossenga, 1991; Root, 1993). Secondly, they prefigure the sustained expansion beginning in the early 1750s of discourse about relations among finance, society, politics and markets (Perrot, 1984: 247; Kwass, 2000: 219, Figure 5.1). Finally, they help illuminate why Old Regime finance persisted until the 1790s, despite critique and attempts at reform.

This article investigates motives for positive representations of finance by analysing writings of Charles Pinot-Duclos (1704-1772) and Charles de Fieux, chevalier de Mouhy (17011784), in overlapping social, intellectual, political and financial contexts. Both authors enjoyed protections traceable to the monarch and royal financial machine. Their apologias praising State ideologies and financial policies reflect indebtedness to patrons and the regime. ${ }^{1}$ Despite this motivated collaboration, however, the financial focus in their writings also emphasizes fraught topics, including changing roles of aristocracy and new elites, and evolving notions of virtue. Unsurprisingly, neither author explicitly critiques royal finance. Yet both raise provocative questions through the topic, suggesting authorial purposes beyond propaganda. The balance of complicity and critique responds pragmatically to personal, social, political and financial dilemmas emerging from forms of obligation.

The study of pro-financier representations and contexts does not merely illuminate past issues of finance, society and obligation. It also contributes to a useable history that sheds light on present-day concerns about modern finance. In France, the suspicion of vast fortunes persists, while sophisticated financial hustlers such as Jérôme Kerviel (Stewart, 2008) vindicate centuries' worth of critique of corrupt financiers and perceived decadence in their lives and working milieus. Published shortly after the 2008 financial crisis, the roman à clef referring to Kerviel, Comment j'ai liquidé le siècle (How I Liquidated the Century), ${ }^{2}$ (Vasseur, 2010) paints a dystopic fantasy. Daily life grinds to a halt when a master algorithm freezes finance capital activity, world markets and electricity production. Such fantastical 'antifinancier' literature from our time has factual counterparts. The work of Thomas Piketty, for instance, whose Le capital au XXIe siècle (Capital in the Twenty-First Century, 2013) deploys data going back to the late eighteenth century, shows France's return to "patrimonial capitalism' or privilege from inheritance. The circumstance contradicts political and social ideals of equality, universality, inclusivity, merit and fair distribution, which economic data and anti-financier fiction reveal as mystifications.

Such critiques notwithstanding, wealth remains an essential cultural aspiration, with finance a privileged domain for fantasies of success. Aspirational financial elitism undergirds titles such as Berrill ou la passion en héritage (Berrill or Passion in Bequest, 2007) by bestselling author Françoise Bourdin. A wealthy banker who inherits the family financial empire, Berrill must decide which of her children should inherit in turn. The drama develops amid trappings of luxury such as large châteaux and beautiful clothes, signaling the appeal of 
achieving wealth and social integration by means of money and finance. This example of current-day 'pro-financier' literature wishfully fantasizes about relations between finance and the individual in society. As an expression of social desire, it instructively mirrors tendencies in the culture. In view of present-day as well as historical contexts, then, this article contributes to a genealogy of pro-finance attitudes. The following pages address how eighteenth-century depictions responded to circumstances from personal indebtedness to financial policy for remediating State obligation by analyzing selected writings of Duclos and Mouhy. To frame this analysis, the next section clarifies the semantic trajectory and Old Regime meanings of the key terms finance(s) and financiers.

\section{The meaning of 'finance(s)' and 'financier' in eighteenth-century France}

Reviewing how usage of the terms finance(s) and financier changed over time highlights the specificity of their Old Regime meanings, based in the relationship to the State. The noun finance derives from the verb finir (to finish or bring to an end). From the thirteenth century, finance meant payment or money, implying the use of money for gifting and buying (Godefroy, 1881, Volume 4: 8). By the fourteenth century, when Valois kings resisted decentralization and established the franc to unify and stabilize currency, the plural finances signified public finances, or the finances of the state. By the sixteenth century, a few financial offices could be purchased, creating revenue for the monarchy (Hamon, 1999: 147-220).

Old Regime definitions for finance(s) and the financier would focus on connections to the State and attendant issues of social re-organization. In 1680, under centralized Bourbon rule and Louis XIV (r. 1661-1715), lexicographer Pierre Richelet emphasized that to use finance as formerly to mean argent monoïe (cash in coins) was low style (Richelet, 1680: 336). Good style, he implies, should not touch upon money, while silver (argent) has better uses than to pay or coin money (monoier/monier). After arbitrating taste, Richelet evokes policies that Bourbon kings pursued extensively to raise money by selling venal offices (ChaussinandNogaret, 1984; Doyle, 1996; Smith, 1996; Maza, 2003: 28-32). The singular finance was now also "Certaine somme d'argent qu'on païe au Roi pour jouir de quelque grace" (Richelet, 1680: 336), the sum of money one pays the King to enjoy some favor, such as an office, with its duties, privileges and prestige.

With royal 'grace' for sale, money pervaded the remnant feudal economy based on reciprocal exchanges of regard, loyalty and gifts. Performing duties of a financial office, moreover, inserted work and specialist knowledge into the noble economy. Richelet (1680: 336) emphasizes that venal offices muddle traditional social distinctions, since a roturier or commoner can now simply pay for fiefs - traditionally, seigniorial lands the monarch bestowed with an honorary elevation, to gain loyalty from a potential rival. That privilege is a business (Durand, 1971: 187) reveals the king's divine right and aristocratic distinction emanating from it as shams. That a transferable sum can purchase elevation shows, too, that the monarchy did not always reinforce 'absolutist' power. Rather, undermining its own legitimacy, it created conditions conducive to reform (Kwass, 2000: 41-43, 60).

The term financier, initially qui finance or he who pays, followed a similar trajectory and by mid-sixteenth century evoked public finances (Chaussinand-Nogaret, 1993: 22-23). At the same time, hommes des finances, or men in public or royal finances such as tax farmers, controllers and receivers, became simply financiers. Richelet's (1680: 336) illustrations for financier convey the official nature of the role and associated responsibility: "Il est bon financier, c'est à dire, il entend bien l'ordre des finances" (He is a good financier, that is, he 
well understands the order of finances). The 'good' financier hews to proper policy administration, affecting the population and State. Yet the term also evoked wealth and corruption, as derogatory phrases show: "Un gros financier, un fameux financier" (A big financier, an infamous financier) (Richelet, 1680: 336). ${ }^{3}$ These descriptions for agents in les finances, who filled numerous roles as State administrators, reflect divided public perception of their trustworthiness.

Distrust fed, too, on generalized prejudice against money and money-making through financial manipulation, or generating coin from coin. This view has roots in Aristotelian political philosophy, as Parsons (2014: 66-76) underlines. In the Politics, Aristotle contrasted limited wealth "necessary to maintain a household" and having "use" or intrinsic value with monetary wealth having "exchange" or surplus value. Because no "natural" limit exists for exchange and monetary gain, accumulation of wealth having surplus value stimulates unbounded desire unrelated to need. Pertinently for finances, he cites usury, monopoly and speculation as producing wealth having "exchange" value unrelated to "use" value (Aristotle, 2015, Book 1, 111: 11-26). In the Nicomachean Ethics he states that a society must find some just manner of distribution to answer the common need for wealth having "use" value and counter the drive to accumulate wealth having "exchange" value (Aristotle, 1999, Book 5, 1-3: 110-20). Since money has value only by convention, it is also in this sense a mere fiction or symbol. By extension, sophisticated uses of money constitute trafficking in artfulness, leading to the excessive wealth accumulation having nefarious consequences for a polity (Aristotle, 2015, Book 1, 9: 22-24).

In France, Aristotelian prejudices persisted despite legitimation of elaborate financial practices. French Christian rhetoric condemned usury and interest-bearing loans, for example, yet laws legitimated forms of interest. As Davis (1960: 22-25) has shown, mathematics and accounting treatises from the late Middle Ages onward detailed computations for common simple and compound interest. In Old Regime statecraft manuals, as Hirschman (1997: 31-66, 69) has argued, the term intérêts (interests), moreover, acquired a primary association with money making and a positive valence so common as to remain virtually unexpressed. By the eighteenth century, reflecting French-style capitalism and State policy, Catholic financiers dominated finances. Nonetheless, theological quarrels raged about lending at interest among other topics (Durand, 1971: 387-79).

With association of the financier to the monarch and State fixed by the late seventeenth century, definitions grew complimentary. In 1680, controller general of finances Jean-Baptiste Colbert consolidated five regional farms into one and improved financial accountability, while the sale of venal offices increased (Doyle, 1996). Aristocratic 'honor' was long associated with military glory and maintenance of prestige of rank. As contemporaries debated the standing of financiers, associations for honor expanded to include honesty, hard work, specialist knowledge and service to the State. The French Academy's first dictionary recommended proper usage of "la langue du Roi" (the language of the King) (Walter, 1984: 383-84; see also Quemada, 1998). It purged criticism from the definition for financier, understood as "Qui manie les finances du Roy" (He who handles the finances of the King) (Dictionnaire, 1694: 460). Financiers extended the authority of the king. They had to profess Catholicism and furnish evidence of social respectability (Chaussinand-Nogaret, 1993: 23). The Académie indicates that a financier might be "rich" or "great" (1694: 460). Infamy and dishonor, evoked by Richelet, are not mentioned.

Despite semantic fixing of the terms finances and financiers, public perception remained divided, as the famous moralist essay on wealth by Jean de La Bruyère (1645-1696) shows. La Bruyère was the lawyer, courtier and royal preceptor whose study Les Caractères, ou les 
moeurs de ce siècle (Characters, or Customs of Our Time, 1688-1694) anatomized social types. In 1673, La Bruyère had used a family inheritance to purchase a venal office conferring noble standing, joining the financial establishment in this way. His chapter 'Les Biens de la Fortune' (The Goods of Fortune) emphasizes the social undecideability of the financier, before re-orienting the reader. Noble courtiers, he writes, dismiss the financier as "un bourgeois, un homme de rien, un malotru" (a bourgeois, a worthless man, a boor), if he is unsuccessful (La Bruyère, 1975: 121). But, La Bruyère drily continues, the courtier will marry his own son to the daughter of a successful financier.

La Bruyère's reflections on how finance fits the changing social order were closely followed by the 1695 levy of a new universal direct tax, the capitation. As Kwass (2000) has emphasized, contemporaries noted the surprising "new arrangement" by which the capitation re-ordered society. Wealthy commoners appeared in a high class. Nobles, if impecunious, ranked low (Kwass 2000: 68, 69 Note 10, 328). ${ }^{4}$ The highest tax bracket included the dauphin and princes, but also farmers-general whose nobility was likely purchased recently (Peron, 1991: 58; Kwass, 2000: 69, 114). Noteworthy are the reduction, in theory, of tax exemptions, the use of wealth before rank for assessments and the sense of shared mechanics among politics, finance and society.

The Old Regime meanings for finance(s) and financier held through the eighteenth century, including the mid-century period that we will examine in greater detail. Mid-century dictionaries confirm that finances refers to the monies of the king, while a financier handles these public funds such as in the General Farm and in connection with other financial affairs of the king (Dictionnaire, 1740: 840; Chomel, 1741: 300-301). In sum, at this time, finance(s) and financier evoked conflations of monarchy and money, obligation between the State and capitalists with their corporations and debates about ordering society and finances.

The next sections examine confrontations of culture, society, politics and finance, in writings of Duclos and Mouhy. Despite overall continuity in Old Regime finance, the 1710s, 1770 s, and 1780s saw attempts at re-structuring. Among these, the 'System' of John Law and its aftershocks concern us here, as reversion to traditional finances followed the scheme's dramatic failure. We now turn to Law's coup, the subsequent financial restoration and our midcentury writers on finance.

\section{Duclos's diplomatic financiers}

The regency of Philippe II, duc d'Orléans (r. 1715-1723) inherited from Louis XIV vast debt, a dearth of credit and coin, and low public confidence. The Scotsman John Law, who killed a man in a duel and fled England in 1694, proposed to reduce France's debt and modernize its finances by asserting State control over their administration. Law consolidated his own reign over the French fisc from 1716, establishing a General Bank, to 1720, when he became controller general of finances. He sought to convert government debt to saleable shares in the Mississippi Company, which would exploit French holdings in Louisiana. Law took French currency off the metal standard and issued paper money. His measures aimed to animate and remake the economy. They resulted in a monopoly over financial transactions, rampant inflation, feverish speculation in Company shares and a spectacular crash starting in May 1720.

After the bubble burst, traditional financiers were recalled to dismantle the failed 'System' and restore order (Murphy, 1997; Neal, 1993; Dale, 2004). Opinions differ about whether Law's innovations were harbingers of modern fiscal organization that failed against 
entrenched interests or nefarious schemes of an unscrupulous gambler. Pertinent for our analysis are the strong reaction and collective trauma the crash caused. Ironically, as Kaiser (1991) has underlined, Law hoped to court public opinion and create confidence with new State financial comportment. Prompt repayment of royal debt, and ready cashing of notes and changing of coins for citizens, for instance, were to have established royal 'credit' and enabled State control of its finances (Kaiser, 1991: 4-6, 10, 18-19). Instead, Law's pyramid schemes collapsed, and citizens sustained losses, producing other effects. The implosion vindicated reversion to traditional finances. Citizens grew wary of banking, paper notes and speculation.

The prestige of financiers in this era is difficult to overstate. Minister Fleury reinvested the General Farm in 1726, then expanded it in 1738 with new lending groups (Vaillé, 1953: 2634). Powerful financiers ran effective administrative hierarchies and enjoyed oligarchic influence in politics and commerce. Jeanne-Antoinette Poisson (1721-1764), of the Le Normant financial clan, was named marquise de Pompadour and installed in 1745 as mistress of France. She was the protégée of Jean Pâris de Monmartel (1690-1766), who with his three brothers became the financial machine behind the army and throne of Louis XV through the 1750s (Dubois-Corneau, 1917). Thus, comments one historian, the "real queen" of France was the wife of a general tax farmer (Chaussinand-Nogaret, 1993: 63). Fleury ostensibly called the farmers-general the 'forty columns' of the state, as financiers and especially tax farmers stabilized the nation (Mathews, 1958: 69-76; Dessert, 1984: 663-65; Doyle, 1996: 121; Ziskin, 1999: 113, 183, n. 64).

The perception of strength of the tax farm had a basis in fact. Historians have underlined its modern aspects, although accusations of brutal collection methods and corruption were common. Kwass (2014: 47) has called it "arguably the most modern institution of the old regime" and "a vanguard of bureaucratic professionalism" responsible for innovations including an employee pension system (see also Durand, 1971: 69; Chaussinand-Nogaret, 1993: 66-67, 71; White, 2004). Tax farming contracts kept pace with expansion of commerce and consumption by specifying proportionate increases into the future. The farm was large, employing 30,000 people. It had privileges for fielding troops and policing (Azimi, 1987: 33; Kwass, 2000: 29-32; Kwass 2014: 72-73, 169-71, 360). These elements contributed to its staying power.

Efficacy made reluctant admirers even of the General Farm's, and France's, critics. The philosophe, novelist and encyclopedist Denis Diderot (1713-1784) famously disliked financiers and criticized tax farmers for excessive wealth and philistine values. Nonetheless, when Diderot received money from Catherine the Great of Russia, he invested it in the General Farm (Durand, 1971: 423, 423, n. 3; see Diderot, 1965: 435-36, 467, 631). Regard for the Farm extended beyond France. When Frederick II of Prussia - France's ally in the War of the Austrian Succession (1740-1748), then enemy in the Seven Years War - reformed excise tax collection, he requested help from farmer-general, philosophe and patron of writers Claude-Adrien Helvétius (1715-1771). Helvétius wrote to the duc de Choiseul: "le roy de Prusse ... veut des François pour régir ses fermes" (the king of Prussia ... wants Frenchmen to administer his farms) and to the duc de Praslin: "la compagnie [de fermiers généraux] est levée et n'attend plus que des passeports pour partir" (the company [of farmers-general] has been assembled and awaits only passports in order to leave). ${ }^{5}$ Helvétius's committee of five financial administrators recruited a 200-strong company of French officers. In collecting funds from Prussian citizens, they helped to centralize the state. ${ }^{6}$

Nonetheless, critics of finances notoriously kept the tax farms in their sights. For if venal offices were structurally compromised, tax farming was the most egregious instance. The fermes or tax farms were corporations formed by wealthy investors. The fermiers or tax 
farmers advanced a bail à ferme or term loan to the monarch and collected indirect or excise taxes. Appointment brought personal privileges and opportunities for profit, along with administrative obligations. Both monarch and tax farmers wanted money and benefited from the arrangement. Yet suspicion of finances and especially the tax farm was logical. The tax farmer was a capitalist with access to the public revenue he collected. He made profits on the difference between money he advanced to the king and revenue collected from taxpayers. The role usurped public power into the hands of individuals (Kwass, 2014: 46), and administrators cultivated personal fortunes by manipulating public funds, drawing the ire of contemporaries.

A significant strain of 'anti-financier' literature aimed specifically at the tax farm. Before Law's intervention, François Fénélon's didactic novel Les Aventures de Télémaque (Adventures of Telemachus, 1699) and manuscript Examen de conscience sur les devoirs de la royauté (Examination of Conscience on the Duty of Royalty, 1711; orig. pub. posth. 1734), written for his pupil Louis de France, ${ }^{7}$ advise against tax farming, which alienates State and aristocratic power (La Mothe-Fénelon, 1995, Book 10: 203-29; La Mothe-Fénelon, 1961, Articles 17-19, 21-22: 93-99). Montesquieu's novel Les Lettres persanes (The Persian Letters, 1721), published as Law's structures were being liquidated, condemns excessive fortunes of tax farmers (Montesquieu, 1995, Letters 48, 98: 110-15, 199-201). In 1749, at the height of power of traditional finances, popular satirical verse called the Poissonnades (Fisheries) mocked the marquise de Pompadour and her brother through their surname Poisson (fish). The stanzas malign perversions of the society and monarchy, blaming financiers for perceived disorder:

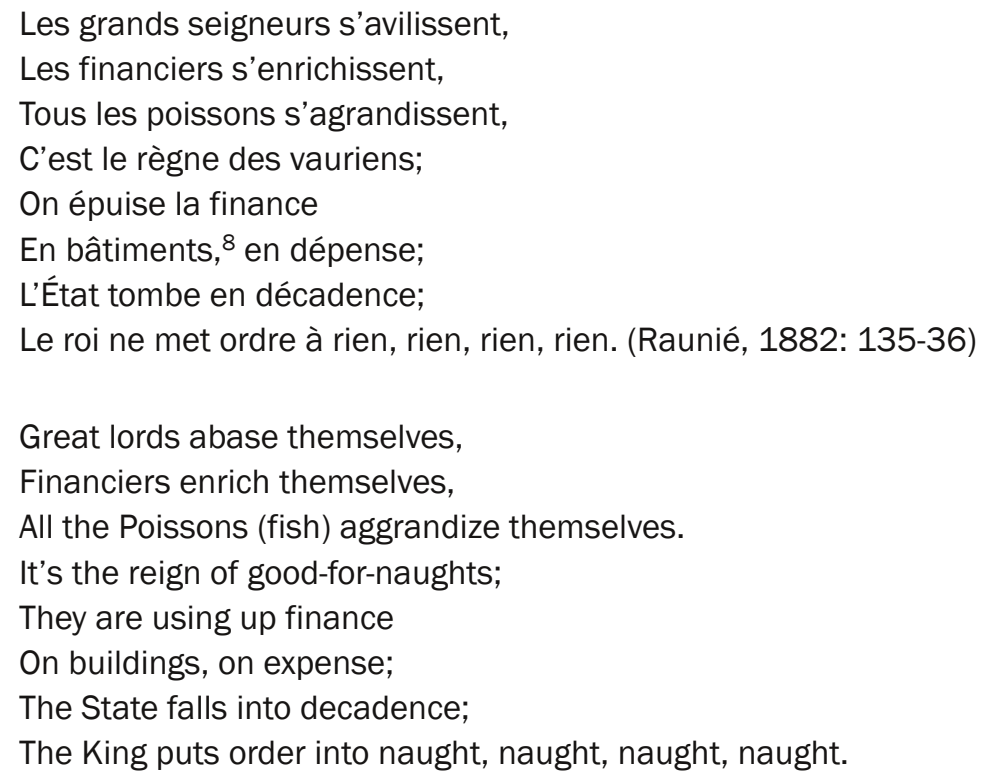

The indictment of tax farming in Montesquieu's treatise De l'esprit des lois (On the Spirit of Laws, 1748) underlines that the practice compromises political and legislative integrity. The comparison among historical and contemporary governments and forms of social organization emphasizes articulations among politics, culture and society. Comparing tax farming to state administered collection, Montesquieu writes that he who has money sets the rules: "Comme celui qui a l'argent est toujours le maître de l'autre, le traitant se rend despotique sur le prince même : il n'est pas législateur, mais il le force à donner des lois" (As he who has money is always master of the other, the financial contractor becomes despotic even over the prince: he is not a legislator, but he forces him [the prince] to give laws) (Montesquieu, 1979, Volume 1, Book XIII, Chapter 19: 369). Tax farming suits only a despotic state, concludes Montesquieu. 
De l'esprit des lois opened the floodgates for critiques of the political economy, but also stimulated defenses of finances. The apologias include writings of Duclos.

Duclos was a novelist, essayist, historian and protégé of the marquise de Pompadour, with obvious motivations to treat finances sympathetically. He became a member of the Académie des Inscriptions et Belles-Lettres in 1739 and the Académie Française in 1746, and the latter's permanent secretary in 1755. The marquise's letter of 5 November 1746 entrusted to Duclos the inscription for a statue of Louis XV and connected him with the duc de Penthièvre. ${ }^{9}$ She also reminded Duclos of her habit "de penser pour vous". ${ }^{10}$ The royal mistress of France was obligingly 'thinking for' Duclos, maneuvering her allies and clients for him. This augured well for him, while incurring obligations for her patronage. In 1750, Mme de Pompadour informed Duclos of another appointment, as royal historiographer: "Je suis ravie ... vous êtes historiographe de S.M." (I am delighted ... you are historiographer of H.M.). ${ }^{11}$ Son of a merchant who dealt in hats and iron, Duclos was received by the king in January 1751.

Beneficiary of powerful connections, Duclos's sense of social reciprocity was not limited to obligation to his own patrons. In the system of favors, he also gave help, such as refusing an academic emolument so another person could benefit. Duclos died with a fortune of 260,000 livres including 50,000 in gold, from accumulated appointments (Brengues, 1971: 15, 61; Brengues, 1970: 41 Note 5). His career extended to politics. He served as mayor of Dinan (1744-1749) and representative of the Tiers to the Breton Estates (1744-1754) (Meister, 1956: $11,15-17)$. Active in multiple spheres, ${ }^{12}$ Duclos built a successful career as a philosophe, public persona and social figure received in salons and in favor at court.

Duclos lacks the iconic reputation of Montesquieu or Diderot, yet contemporaries in France, England, Spain and Germany read his works, ${ }^{13}$ pointing to their interest for understanding attitudes about finances. In a survey of 500 private library catalogues from mid-century, Duclos's works appear frequently (Mornet, 1910: 460-61, 473-75). Both his memoir-novel the Confessions $d u$ comte de $* * *$ (Confessions of Count $* * *, 1741-1742$ ) and essays Considérations sur les moeurs de ce siècle (Considerations of the Customs of Our Time, 1751) saw eleven editions each in the author's lifetime, indicating broad appeal. ${ }^{14}$ Academician Jean-François Marmontel read the Considérations in a night and complimented Duclos as a "benefactor of humanity". ${ }^{15}$ Montesquieu favorably compared Duclos to La Bruyère: "vous êtes plus philosophe que lui ... agréable à lire"16 (you are a better philosophe than he ... agreeable to read). The compliments are measured. Duclos's social prominence may have motivated contemporaries unwilling to sacrifice cordial relations.

Although a popular writer in his time, Duclos's social prestige begs the question whether he wrote to further protectors' agendas. Both the Confessions and Considérations connect 'virtue' with money, communicating harmony with finances. The Confessions spoofs libertinage to praise philanthropy, work and love between like-minded individuals - the protagonist is a debauched noble who reforms through finances. Tiring of seduction, the Count finds finance a better investment, both productive and hygienic: "Pour me guérir radicalement ... je résolus de vivre quelques temps dans la finance, ${ }^{17}$ et ce remède me réussit" (To take a radical cure ... I resolved to live for a time in finance, and this remedy worked for me) (Duclos, 1992: 108). Financiers, the Count learns, work hard and think of the future. He praises their success, due to cultivation of family ties, education and industry. Such are the new habits and attitudes the dissolute count adopts.

Through finance the Count discovers a new sociability based in moral investments and reciprocity, or mutual obligation. Leaving seduction behind, he now assists others and loves one woman. Self-interest motivates the change. Helping an impoverished couple, he discovers that the pleasure of giving assistance multiplies returns to himself. The notion of virtuous 
investment also informs a patriotic statement about finances: “Je sais que personne n'a encore osé en parler avantageusement ... La finance est absolument nécessaire dans un État, et c'est une profession dont la dignité ou la bassesse dépend uniquement de la façon dont elle est exercée" (I know that no one has yet dared to speak of it advantageously ... Finance is absolutely necessary in a State, and it is a profession whose dignity or baseness depends uniquely on the way it is practiced) (Duclos, 1992: 108-109). Addressing public perception, Duclos relativizes anti-financier sentiment as anachronistic and financial malfeasance as owing to human foibles not unique to financiers.

The novel's conclusion reconciles love and virtue with a financial metaphor: "Nous jouissons de cette union des coeurs, qui est le fruit et le principe de la vertu. Ce qui m'attache le plus à ma femme, c'est que je lui dois cette vertu précieuse, et sans doute elle me chérit comme son ouvrage" (We enjoyed this union of hearts, which is the fruit and the principle of virtue. What binds me most to my wife is that I owe her this precious virtue, and doubtless she cherishes me as her work) (Duclos, 1992: 180). The good life, concludes the Count, rests on wise investments of monetary and social capital as well as balanced social debts and credits. $^{18}$

When controller general Machault d'Arnouville prolonged the universal vingtième tax after the War of the Austrian Succession, Duclos refrained from joining efforts of his Breton parliamentary colleagues to protect their own exemptions and privileges. Duclos did not attend the Breton Estates meeting convened to oppose the Edict of Marly of 6 May 1749 converting the dixième to the universal vingtième (Brengues, 1971: 65). In 1750 Duclos did not explicitly support colleagues in the Estates who sent a 27-article brief to the king expressing opposition to the vingtième. In 1752, the Breton Estates sought to obstruct passage of the vingtième by refusing to deliberate the topic. Duclos was not welcome at the meeting, indicating lack of cooperation with his colleagues (Brengues, 1971: 65, 81, 87, 87 n. 31). Duclos neither participated in the campaign waged by fellow parliamentarians, nor defended the monarchy and Machault d'Arnouville's policies. The diplomatic silence invites interpretation.

The essays in Duclos's Considérations return to themes of money and finance to diagnose 'anti-financier' sentiment as stemming from envy. The chapter 'Les gens de fortune' (People of means) emphasizes that criticism of gens de finance often lacks cause. Rather, "c'est l'envie qui poursuit le faste" (it is envy that pursues splendour), a case of desire chasing display. As he astutely notes, 'we' all need to stay financially afloat, and we may want to get ahead. He concludes: "Voulons-nous avoir le droit de mépriser les riches? Commençons par mépriser les richesses; changeons nos moeurs" (Do we want the right to disdain the wealthy? Let us begin by disdaining wealth; let us change our customs) (Duclos, 2005: 178, 181). For Duclos, re-definition of social status and honor through wealth has already taken place. The dilemma consists in knowing what constitutes 'virtue' in a money- and finance-based social and political economy. Where do obligations lie? Who owes what to whom?

The Considérations does not overtly criticize finances, although social commentary provides the platform for pursuing financial topics. Duclos had reasons to align with the monarchy and its financial policies. During his youth, his mother lost money in the Law scheme. He later denounced Law, in a phrase recalling Montesquieu, for financial "despotism more frenetic" than any known (Duclos, 1808, Volume 2: 24). Within the Considérations, the 'change of customs' or mores may praise monarchic financial policies such as the vingtième, a direct tax on income, which through a universal levy would change the culture, making it more egalitarian. In 1751, responding to Duclos's request, Louis XV accepted, via the duc de Gesvres, dedication of the Considérations: "le Roy vous permet de luy dedier cet ouvrage" (the King permits you to dedicate this work to him). ${ }^{19}$ The second edition, also dating to 1751 , 
bears Duclos's dedication to the king (Duclos, 2005: 93). Duclos had every reason to cultivate his works to please his protectors.

Interestingly, the dedication to the Considérations strikes a note of independence, even while negotiating a delicate situation. In September 1750 Duclos had become a royal historiographer, yet the Considérations addresses social custom. Duclos opens the dedication by promising to cease such creations, henceforth devoting himself to works of history about the monarch's deeds. He rhetorically reifies his personal connection to the king, however, stating his "avantage" for depicting not only the glorious, active statesman or "Hero and Peacemaker of Europe', but also his exemplary character: "le Roi vertueux, le Prince à qui I'humanite est chère" (the virtuous King, the Prince to whom humanity is dear) (Duclos, 2005: 93). Duclos in this way folds history into the 'moral' observations about social custom constituting his Considérations. By implication, his treatise, emerging from privileged observation, participates in history.

In fact Duclos's diplomatic rhetoric keenly appraises political and social affairs, recalling Montesquieu as much as La Bruyère. Unperturbed by sophisticated finance and the money economy, neither the Confessions nor Considérations evokes specific institutions such as the tax farm. Both texts leave open the possibility that Duclos might ultimately side with critics. Montesquieu's De l'esprit des lois weighs, as we saw, on political defects of tax farming, and further reflects on relationships such as among equality, individual frugality and public expenditure in democracies (Montesquieu, 1979: Books V, XIII). The subtitle of the Considérations conjures La Bruyère's Caractères, as Montesquieu remarked; however, Duclos considers behaviors and sentiments in larger contexts. As a modern commentator observes, this made the Considérations sociological, avant la lettre. ${ }^{20}$ Duclos admired De l'esprit des lois, which he read upon its publication. That work's avoidance of dogma and exploration of interrelations among social, political and economic spheres (Brengues, 1971: 63) fits the Considérations, too.

At home among gens de lettres and gens du monde, as Turnovsky has stated (2010: 8283, see also 66 and 95), Duclos's financial discourse illustrates that neither a philosophical ideal of independence, nor the notion of a creature controlled by debt to benefactors and court, adequately mirrors the lived experience. Counterbalancing the royal dedication, Duclos appears in the 'Introduction' to the Considérations as a "Citoyen de la liberté" (Citizen of liberty) serving truth and utility: "Si l'Ouvrage plaît, j'en serai très-flaté ... encore plus content, s'il est utile" (If the Work pleases, I will be very flattered ... even happier, if it is useful) (Duclos, 2005: 95). Duclos's canny writings leave open the possibility that he was as critical as Montesquieu of institutions such as the tax farm, although he refrained from critiquing it directly and from deriding the monarchy dependent upon it, thus from spiting those to whom he owed so much.

The following pages examine the strategy of compliance and critique of a contemporary to Duclos. Mouhy's was a wholly different persona from that of the diplomatic historiographer and chronicler of social politics. Yet he also wrote explicitly about finances from a proximate standpoint

\section{Mouhy's fantastical financier}

Following the War of the Austrian Succession, Parisian and other parlements grew unwilling to register fiscal measures to pay war debt and ensure a revenue stream. During the war, the monarchy had levied extraordinary taxes from a dixième in 1741 that was increased in 1742, to measures of 1748 to exact duties on tallow, candles, stamped paper for notarial acts and 
cardboard; oblige seigniorial landholders to purchase exchange rights on their own land or risk forfeiting them; and apply the centième denier tax on the transfer of offices and real estate (Rogister, 1995: 33, 62). But after the war, Machault d'Arnouville's 1749 prolongation of the vingtième - the proportional revenue tax imposable upon "each and all" subjects (Kwass, 2000: 42) - provoked contentious debates between monarchy and parlements. The measure drew resistance into the mid-1750s from magistrates, as in Brittany, and clergy, as it would reduce tax exemptions - important markers of privilege - for both groups (Rogister, 1995: 62121). In the battle between king and privileged groups, the monarch used lettres de cachet (royal sealed letters) to exile senior Paris Parlement members, causing Parlement temporarily to cease functioning (Rogister, 1995: 216).

In this tense atmosphere Mouhy published his paean to finance, the novel Le Financier (The Financier, 1755). Like Duclos, Mouhy enjoyed important contacts and certainly more distinguished family connections. His uncle Hilaire Bernard de Requeleyne, baron de Longepierre (1659-1731), was a minor playwright and preceptor to the comte de Toulouse ${ }^{21}$ and Philippe d'Orléans, duc de Chartres, nephew to Louis XIV and regent during the minority of Louis XV. His uncle introduced Mouhy to distinguished circles of the kind where Duclos flourished. His persona and career otherwise little resembled those of the urbane academician.

Little read today, Mouhy was a prolific producer of minor novels. Estimates range from 40 to as high as 80 , including anonymous and foreign imprints. For playwright and antiphilosophe Charles Montenoy de Palissot (1730-1814), Mouhy exemplified an "insipid style" and "inane genre" (Rivara, 2010: 14 n. 9) that lacked originality and substance. Journalist and literary critic Charles Monselet (1825-1888) catalogued Mouhy among "forgotten and disdained" writers, stating that he produced only one good novel (Monselet, 1876: 267-73). Another critic qualified Mouhy as "truly the most boring of eighteenth-century novelists" (d'Estré, 1897: 195). Although hardly respected by writers or critics, his novels appealed to contemporary readers in France and abroad (Cointre, 2010: 99-110). Recently, literary specialists have shown new interest in Mouhy (see Cointre, 2010; Kahan, 2010; Magnot, 2010; Rivara, 2010).

For Mouhy, as for Duclos, creative endeavor and practical pressure inform treatment of finances. By age 40, Mouhy had five children and a wife to support, with social entrée into "the society of grandees and finance" and his pen for resources (d'Estré, 1897: 196; see Shaw, 1955: 114-16). What he lacked, perpetually, was money. In 1741 his prurient novel Les Mille et une faveurs (The Thousand and One Favors) attacked Louis XV and his mistresses and ministers. Police lieutenant Feydeau de Marville threw the author into the Bastille, then relented after a month, possibly responding to Mouhy's supplications that he must support his family. More certain was the utility of Mouhy's connections. Forsaking slander, Mouhy became a nouvelliste (news compiler) and mouche (informant) for the Paris police. He listened in cafés, theatres and houses such as of controller general Philibert Orry and Voltaire, who received him. He quizzed interlocutors for information, attending to circulating noises and news (d'Estré, 1897: 203, 206, 217, 224, 230). He sent weekly manuscript gazettes to individuals outside Paris and daily supplied information to Merville, who informed the government about public opinion. Merville edited Mouhy's reports, passing his redactions to the minister Maurepas (d'Estré, 1897: 200).

The news gathering operation of the monarchy, to which Mouhy contributed, sought public response to finances. As Darnton (1984) observed in studying reports on writers compiled by Joseph d'Hémery, inspector of the book trade, tax reforms of Machault d'Arnouville, and by extension, the monarchy itself, were drawing heavy criticism. A "spy's 
account", for example, reports strong statements about the vingtième made in the Parisian café Procope: “someone ... ought to wipe out the whole court, whose sole pleasure is to devastate the common people and perpetrate injustice'" (Darnton, 1984: 25; see also Darnton 1985: 145-89, 276-77). Informed of public ire, the State published edicts describing how the new taxes would promote "equality" and "justice" across the society (Kwass, 2000: 42). Durand (1971: 419) has suggested that, in this climate, Mouhy's novel could have been written on commission, such as to further the monarchy's public relations campaign or enhance the reputation of financiers. Mouhy's need for money; strategic turn toward the monarchy; connections to courtiers and financiers; and flattering portrayal of finances, together suggest that Le Financier could well have been conceived to repay debts and affirm bonds of obligation with protectors.

Mouhy enrolled, moreover, his 'pro-finance' novel in another battle of opinion, as well. The 1739 'proscription' on publishing novels, due to their doubtful morality and utility, hardly prevented the flow of fictions (Weil, 1986; Weil, 1999). Even so, the atmosphere relaxed when liberal aristocrat and magistrate Lamoignon de Malesherbes assumed oversight of the book trade in 1750 (Grosclaude, 1961: 63-80; Martin, 1984: 74-75; Roche, 1984: 78-82). The easing spurred the reactionary Entretiens sur les romans (Conversations on Novels, 1755) by the abbé Jacquin, who inveighed against the moral dubiousness of fictions which could dupe readers. Mouhy refutes Jacquin's argument in the prefatory 'Essai pour servir de réponse à un ouvrage, intitulé Entretiens sur les Romans, par M. l'Abbé J.' (Essay to Serve as Response to a Work, entitled Conversations on Novels, by M. I'Abbé J.) (Mouhy, 1755, Volume I: i-xx), holding that no writer could produce such a noisome work as the cleric imagines (see Kahan, 2010: 199-202). Mouhy's Le Financier then follows, a convenient example a contrario of a moral novel.

Le Financier offers an idealized portrait of a tax farmer serving a benevolent monarch and the people, through an economics of secular virtue. The protagonist D'Argicourt's name recalls argent (silver/money) and cour (court). He is honorable, enlightened, sensible, industrious and generous, within a society where ties remain feudal, and privilege still aspires to aristocratic status. The mixing of aristocratic and non-aristocratic elite values recalls recalibrations of the social order that we have encountered. The portrait of wealth and virtue suggests a fantasy, yet the novel accurately portrays habits of financial dynasties, as confirmed by later historians.

The novel also echoes the moral improvement through finances that Duclos recounted in the Confessions. In a genealogy of the protagonist, the opening pages reveal how d'Argicourt's father Monchamps worked to improve his standing, becoming a financier serving the king. After falling into "typical dissipations" of the rich, Monchamps, too, reforms, in a worldly mode. Using his wealth for gifts and interest-free loans, Monchamps enjoys the gratitude of others who "allow" him to do good (Mouhy, 1755: Volume I, i: 1). Rhetoric rationalizing the tax farmer's excessive wealth frames financial philanthropy in terms of humility and sympathy, not religion or glory (see Durand, 1971: 416). Similarly, sentimental identification among individuals of 'virtue' obscures differences in standing and wealth. At bottom, however, philanthropy here equates to scattering largesse. The relationship between donor and recipients remains asymmetrical and accidental. Credit and reputation accrue to Monchamps, making "bien faire" (doing good) part of a circuit of exchange, not a gratuitous act. Rewarding Monchamps' zeal in serving "King and fatherland," the monarch grants him a noble title (Volume I, i: 1). The Enlightenment principle of perfectibility as well as demonstration of fealty and the enactment of an originary elevation transform the financier, setting him on the virtuous path. 
As if laying to rest the 'lackey-financier' or rags-to-riches myth that historians would disprove, Le Financier enumerates the vast resources that Monchamps invests in his son to prepare d'Argicourt to work in finances. D'Argicourt inherits intellect and social advantages from his father (Volume I, i: 4-5), but education fixes the legacy. D'Argicourt has a mentor and benefactor in his father and a tutor who encourages his taste for the sciences and letters, builds his character to "le véritable honneur \& l'extrême probité" (true honor and extreme probity) (Volume I, i: 8-9), and travels with him on working voyages (Volume I, i: 105; Volume I, ii: 60-66; Volume II, iii: 6). Monchamps grooms his son for a career in finances and purchases the amenities. To "two million" that an uncle gives d'Argicourt, Monchamps adds another fortune and obtains the post of farmer-general for his son (Volume I, i: 2-3, 6, 10). Preparations complete, d'Argicourt glides into the role of honorable citizen and distinguished financier (Volume I, i: 11). Notably, money, merit and effort are requisite components to establish standing for d'Argicourt.

At this point, the reader has advanced a dozen pages into the narrative; more than 800 remain. The station of d'Argicourt represents an ideal of advancement sure to interest any reader dreaming of or actually intent on improvement. The novel addresses relevant questions, revealing its usefulness as a guide. D'Argicourt is primed to succeed: What comes next? At issue now is how to carry out daily work, protect standing, fulfill the self and find social outlets for financial philanthropy. D'Argicourt's virtue contrasts markedly with diabolical traits imputed to fameux - infamous or corrupt - financiers.

Evocations of financial work emphasize conscientiousness, countering popular associations with parasitism and exploitation and implying new definitions for honor. If leisure, replacing military exploit, still often marked the aristocrat, then d'Argicourt hardly qualifies. Due to work-related deadline or appointment, he regularly delays engagements of friendship and family (see, for instance, Volume II, v: 126). Upon meeting the woman who later becomes his wife, the chaste financier feels extraordinarily moved. Yet because of working obligations, he temporarily separates from her to complete his tasks (Volume II, iii: 49). The aristocratic obligation of honor transmutes into the dutiful accomplishment of work, which serves the king.

The novel is remarkable for portraying the financier's professional circle. In Le Financier, cultivation of contacts and protectors builds the financial network, in which individuals work autonomously but maintain alliances:

Quand M. d'Argicourt eut dîné, il alla faire des visites jusqu'à quatre heures; il les termina par celle d'un Sous-Fermier nommé la Villiere, qu'il aimoit beaucoup, \& à qui il devoit les connoissances profondes qu'il avait acquises dans son métier. (Volume I, ii: 4-5)

After Mr. d'Argicourt had dined, he went to pay calls until four o'clock; he finished with one to an UnderFarmer named La Villiere, whom he greatly liked, and to whom he owed the profound knowledge acquired in his métier.

The 'Under-Farmer' and d'Argicourt are collaborators and friends. Such visits recall social rounds made in aristocratic leisure, but they cement working alliances as well as bonds of mutual obligation, through exchanges of knowledge and trust. The novel nowhere depicts the policing of salt and tobacco concessions carried out by the General Farm. The reader finds no collection of tax, balancing of accounts, or meeting of financial council. Rather, the narrative portrays social interactions that facilitate administration and emphasize financial respectability.

The conversion of hard coin into gifts forestalls any tendency to limitless acquisition and justifies financial fortune. The excess of d'Argicourt's riches, siphoned off as gifts, becomes 
wealth with use-value (in Aristotelian terms) for recipients in need. D'Argicourt's chance meetings with unfortunates, occasioned by business travel, highlight his generosity. He listens sympathetically to the destitute and helps the sick. To the wife of a repentant gambler, he gives "fifty thousand écus" (Volume I, i: 26). To an impoverished banker whose wife lies ill, he sends medical assistance and a full coin purse (Volume II, iii: 9-11). The financier, in other words, remediates injustice and misfortune with kindness and cash. The jouissance or interest reaped consists in the gratitude of the beneficiaries, the satisfaction of helping and dividends in reputation or "regard" (Offer, 1997: 455, 457) from others.

A secular redeemer, the financier puts economics in the social agenda. Beneficent actions, it is clear, require means that finance increases. The louis and francs mentioned in precise quantities contribute to a moral accounting. The economic and social flow unites disparate individuals: financiers of Paris meet those of Lyon, the city dweller encounters denizens of a country estate. As d'Argicourt moves about France on fiscal errands, money, knowledge and virtue flow with him and, ostensibly, back to the monarch. Far from troping corruption or exploitation, money is the necessary tool to accomplish good deeds and the ultimate weapon to counter harmful actions. Proper use of fiscal resources accomplishes duty, realizes humanitarian ends and subdues vice, upholding an economy of virtue.

The slow-moving marriage plot frames the explicit defense of financiers against class prejudice, earlier critiqued too by La Bruyère and Duclos. While wealthy d'Argicourt is a new elite, Mlle Versan, his beloved, issues from ancient aristocracy. Skeptical about her wooer's profession, Mlle Versan refuses, despite her poverty, to "descend" by marriage into "la classe Bourgeois" of non-aristocratic elites, which she professes not to know (Volume II, v: 7; see also Volume II, v: 16). Nonetheless, she and d'Argicourt share interests and inclinations. The lovers' quarrel turns on the familiar question about the blurring of traditional castes. D'Argicourt's passionate declaration defends financiers, natural sentiment and earned honor:

Donnez-vous la peine de comparer les Financiers de ce siécle avec ceux qui les ont précédés ... Nés d'hônnetes gens: souvent alliés à de grandes Maisons, que les richesses de ceux-ci ont mis en état de servir utilement le Roi \& la patrie, ils ont acquis cette façon de penser estimable \& relevée, qui les égalent en quelque façon à l'homme de condition, par les qualités du coeur \& de l'ame; d'ailleurs l'éducation ornée qu'ils reçoivent, leur ont inspiré de bonne heure les sentimens qui caractérisent l'honneur \& la vertu. (Volume II, v: 81-82)

Trouble yourself to compare the Financiers of this century with those who came before ... Born of gentlemanly people, often allied to great Houses that the riches of the former enabled usefully to serve the King and the fatherland, they have acquired that esteemed and elevated way of thinking that makes them in some way equal to the man of rank, through the qualities of heart and of soul; what is more, the elaborate education that they receive early inspires in them the sentiments that characterize honor and virtue.

Elsewhere, d'Argicourt appeals to the "wit", intellectual "penetration" and "reason" of Mlle de Versan, as against "unjust caution" due to outmoded ideas. He builds an enlightened argument for the essential good in people and the improving forces of effort and education (Volume II, v: 80). To think otherwise is nonsensical, since industrious, valorous individuals such as financiers now prop up the aristocracy.

D'Argicourt's manifesto turns on an anti-Aristotelian conception of money and finance, defined in relation to passion. He impugns celibacy as "sterile" (Volume II, v: 17), a denial of humanity and natural sociability. As an exchange of economic and social capital, his marriage with Mlle de Versan will concretely benefit both. Yet his arguments for passion and finance hinge on the transformation of money into philanthropy and service to the State. Evoking Old 
Testament passages on charity, d'Argicourt describes how his re-distribution efforts repair caprices of fate, help widows and orphans and rescue merit from indigence (Volume II, v: 8485; see also Volume II, v: 156). Accumulation of money in finances and its release through philanthropy procure a "sensual delight" (volupté) that d'Argicourt "enjoys" (jouir) (Volume II, iv: 113-14; Volume II, iv: 161-62; Volume II, v: 84-85). These terms also designate sexual release, from a materialist standpoint the most essential, natural pleasure of all. As finance becomes the most virtuous and natural of professions, however, sentimental morality verges on caricature. The luxury and security available to farmers-general undoubtedly fascinated the impecunious novelist and many readers, while its virtuous depiction flattered finances. Yet Mouhy's financial fantasy shows gaps between rich and poor, elite and non-elite, making the case for re-thinking both social obligation and economic distribution.

\section{Conclusion}

So strongly were the terms finances and financier associated with the Old Regime constellation of individual and corporate capital investment, public functions and monarchy that their traditional definitions endured even after the revolutionary National Assembly suppressed the General Farms in 1791, halted the sale of venal offices, and extinguished the monarchy with the regicide of Louis XVI in 1793. In 1798, the fifth edition of the Academy's dictionary still defined a financier as he who handles the finances of the King. The same edition, however, is also the first to disconnect the financier from the king, moving toward modern usage: "On appelle aussi Financier, dans le commerce, un homme riche, qui a fait une grande fortune" (One also calls a Financier, in commerce, a rich man, who has made a great fortune) (Dictionnaire, 1798: 588). The connection with wealth now inhabits a domain that includes commerce, but no longer implies the State, much less the monarchy. A nineteenthcentury definition - "Celui qui fait des opérations de la banque, des grandes affaires d'argent" (He who carries out banking operations, important money transactions) - without explicit reference to the State signals the transition to modern forms of commercial and private finance and the partitioning of public monies from private interests (Littré, 1872-1877). The mutation of finances into economics, and the separation of politics from economics into distinct spheres, chime with Polanyi's classic argument in The Great Transformation (1944).

Nonetheless, the persistence of the old associations even after the Revolution of 1789 underlines the force of royal finances through the eighteenth century. Even its critics were often heavily invested in it, whether through money, social connections, political ties or all three. In these contexts, laudatory pages about finances by Duclos and Mouhy scan as propaganda. Yet their writings propose a subtler critique than blatant 'anti-financier' expression. Acknowledging obligations and bonds to the financial establishment, protectors and patrons, they make plain the difficulties less of imagining better structures for the future, than of actually making changes to adopt them. These authors and their protectors recognized conflicts and the structural production of social and economic inequality in the society. The writings of Duclos and Mouhy about finance and society make clear how much there was to lose - from personal standing and social ties to economic security - for so many, in making drastic changes to the status quo. In this sense, their depictions of virtuous financial culture take on exceptional relevance for today's readers. They stand as revealing mirrors for presentday predicaments and our own bifurcated financial discourse, which ranges from moral condemnation, intellectual suspicion and critique, to aspirational views of wealth and luxury attaching to modern realms of finance, business and inheritance. 


\section{Notes}

1. For patronage and clientelism in Old Regime politics, see Kettering (1986: 12-40). For cultural patronage, including by financiers, see Bailey (2002) and Blanning (2002). For patronage and literary culture, see Shoemaker (2007). For State patronage and printers, see McLeod (2011).

2. Throughout the article, translations of French into English appear in brackets. All translations are by the author.

3. A partisan, a term that appears in Richelet (1680: 336), was engaged by contract or partie, such as a tax farmer or other financial backer, but assumption of self-interest informed usage of this term. Other terms connoting profiteering and corruption included maltôtier ([ruthless] collector of [punishing] tax), agioteur (discounter of financial paper), and traitant ([untrustworthy] financial contractor) (Dent, 1973; Azimi, 1987; Antoine, 2003; Félix, 2011).

4. Kwass cites the Gazette d'Amsterdam, 1695, from A.M. de Boislisle (ed.) (1874-1928) Mémoires de Saint-Simon, vol. 2. Paris, 464.

5. Letter 596, 'Helvétius à Etienne François, duc de Choiseul [Septembre 1765]' and Letter 597, 'Helvétius à César Gabriel de Choiseul-Chevigny, duc de Praslin [Septembre 1765]' (Helvétius, 1991: 238-39).

6. 'Introduction'; and see Letter 585, 'Helvétius au protecteur de Jean-Baptiste François Veilh, Juillet 1765'; Letter 591, 'Frédéric II, roi de Prusse, à Jean-Baptiste de Boyer, marquis d'Argens, Ce 19 [août 1765]'; Letter 594, 'Helvétius à Charles Augustin Feriol, comte d'Argental, [...] 1765' (Helvétius, 1991: x, 182, 213, 216-20, 229-31, 234-35).

7. Louis de France, duc de Bourgogne (1682-1712) was a grandson of Louis XIV and the father of Louis XV.

8. Louis XV named the marquise de Pompadour's brother, Abel-François Poisson de Vandières, marquis de Marigny (1727-1781) to inherit the office of Directeur Général des Bâtiments du roi, Académies et Manufactures on the death of controller general of finances Philibert Orry in 1747, and following its occupation by tax farmer Charles François Paul Le Normant de Tournehem, Marigny's uncle by marriage. From 1751-1773, Marigny was Directeur des Bâtiments du roi, Arts, Jardins et Manufactures.

9. The duc de Penthièvre (1725-1793) was the richissime Louis-Jean-Marie de Bourbon, natural grandson of Louis XIV and Mme de Montespan, whose father had been legitimized.

10. Letter 12, 'A Monsieur Duclos, maire de Dinan, à Rennes, Bretagne', from 'La M.ise de Pompadour' (Ce 5 novembre [1746]) (Brengues, 1970: 13).

11. Letter 20, 'Monsieur Duclos à Rennes', from 'La M.ise de Pompadour' (Ce 11 [octobre 1750]) (Brengues, 1970: 25).

12. On the integration of social, cultural, and political spheres, including finance, see Durand (1971: 503-49); Chaussinand-Nogaret (1993: 121-45); Lilti (2015: 29-33); Guichard (2012: 519-47); Sewell (2010: 119); Crowston (2013: 8, 332 n. 22).

13. Dornier, 'Introduction' (Duclos, 2005: 55).

14. Versini, 'Présentation' (Duclos, 1992: 7) and Dornier, 'Introduction' (Duclos, 2005: 71).

15. Letter 25, 'Marmontel' to Duclos, [1751; n.d.] (Brengues, 1970: 33).

16. Letter 26, Montesquieu to Duclos, 'De Paris, ce 4 mars 1751' (Brengues, 1970: 34).

17. Unusually, Duclos uses the singular la finance, where les finances was habitually used.

18. Compare Chapter 7, 'Sur le crédit', in Duclos (2005: 156-60) and Crowston (2013: 78-88, 80).

19. Letter 28, '[L]e duc de Gesvres' to Duclos, 'A compiegne le 4 juillet 1751' (Brengues, 1970: 37; see also Brengues, 1971: 83).

20. Dornier, 'Introduction' (Duclos, 2005: 15).

21. The comte de Toulouse, Louis-Alexandre de Bourbon (1678-1737) was a legitimized natural son of 
Louis XIV and father of Duclos's contact through Mme de Pompadour, the duc de Penthièvre.

\section{References}

Antoine, M. (2003) Le Coeur de l'État: Surintendance, contrôle général et intendances des finances, 1552-1791. Paris: Fayard.

Aristotle (1999) Nicomachean Ethics, translated by M. Ostwald. Upper Saddle River, NJ: Prentice Hall.

Aristotle (2015) The Politics, translated by J. Barnes. In: Everson, S. (ed.) The Politics and The Constitution of Athens. New York, NY: Cambridge University Press, 11-207.

Azimi, V. (1987) Un modèle administratif de l'ancien régime: Les commis de la ferme générale et de la régie générale des aides. Paris: Centre National de la Recherche Scientifique.

Bailey, C.B. (2002) Patriotic Taste: Collecting Modern Art in Pre-Revolutionary Paris. New Haven, CT: Yale University Press.

Blanning, T.C.W. (2002) The Culture of Power and the Power of Culture: Old Regime Europe, 16601789. Oxford: Oxford University Press.

Bosher, J. (1970) French Finances, 1770-1795: From Business to Bureaucracy. New York, NY: Cambridge University Press.

Bossenga, G. (1991) The Politics of Privilege: Old Regime and Revolution in Lille. New York, NY: Cambridge University Press.

Bourdin, F. (2007) Berrill ou la passion en héritage. Paris: Belfond.

Brengues, J. (ed.) (1970) Correspondance de Charles Duclos (1704-1772). Saint-Brieuc: Presses Universitaires de Bretagne.

Brengues, J. (1971) Charles Duclos (1704-1772) ou l'obsession de la vertu. Saint-Brieuc: Presses Universitaires de Bretagne.

Chaussinand-Nogaret, G. (1984) La Noblesse au XVIIle siècle: De la féodalité aux Lumières. Brussels: Complexe.

Chaussinand-Nogaret, G. (1993) Gens de finance au XVIIle siècle. Paris: Complexe [orig. pub. 1972].

Chomel, N. (1741) Dictionnaire Oeconomique. Commercy: Thomas [orig. pub. 1709]. Available at: <http://www.cnrtl.fr/dictionnaires/anciens/chomel/lorraine.php/>. Accessed 16 July 2016.

Cointre, A. (2010) La paysanne parvenue en Angleterre. In: Herman, J., Peeters, K. and Pelckmans, P. (eds.) Le Chevalier de Mouhy: Bagarre et bigarrure. New York, NY: Rodopi, 99-110.

Crowston, C.H. (2013) Credit, Fashion, Sex: Economies of Regard in Old Regime France. Durham, NC: Duke University Press.

Dale, R. (2004) The First Crash: Lessons from the South Sea Bubble. Princeton, NJ: Princeton University Press.

Darnton, R. (1984) Policing writers in Paris circa 1750. Representations, 5(1): 1-31.

Darnton, R. (1985) The Great Cat Massacre and Other Episodes in French Cultural History. New York, NY: Vintage [orig. pub. 1984].

Davis, N.Z. (1960) Sixteenth-century French arithmetics on the business life. Journal of the History of Ideas, 21(1): 18-48.

Dent, J. (1973) Crisis in Finance: Crown, Financiers and Society in Seventeenth-Century France. London: St. Martin's.

Dessert, D. (1984) Argent, pouvoir et société au Grand Siècle. Paris: Fayard.

d'Estré, P. (1897) Un journaliste policier: Le Chevalier de Mouhy. Revue d'histoire littéraire de la France, 4(2): 195-238.

Dictionnaire de l'Académie française, dédié au Roy (1694). Paris: Jean Baptiste Coignard. Available at: <http://portail.atilf.fr/dictionnaires/ACADEMIE/PREMIERE/premiere.fr.html/>. Accessed 16 July 2016.

Dictionnaire de l'Académie française (L'An Vl/1798), 5th ed., vol. 1. Paris: J.J. Smits. Available at: 
<http://portail.atilf.fr/dictionnaires/ACADEMIE/CINQUIEME/cinquieme.fr.html/>. Accessed 16 July 2016.

Dictionnaire universel françois et latin contenant la signification et la définition tant des mots de l'une et l'autre langue, avec leurs différents usages, que des termes propres de chaque état et de chaque profession [Dictionnaire de Trévoux] (1740). Nancy: Pierre Antoine. Available at: <http://www.cnrtl.fr/dictionnaires/anciens/trevoux/>. Accessed 16 July 2016.

Diderot, D. (1965) Lettres à Sophie Volland, edited by Y. Florenne. Paris: Le Club français du livre. Doyle, W. (1996) Venality: The Sale of Offices in Eighteenth-Century France. Oxford: Oxford University Press.

Dubois-Corneau, R. (1917) Paris de Monmartel, Banquier de la Cour. Paris: Meynial.

Duclos, C. (1808) Mémoires secrets sur le règne de Louis XIV, la régence et le règne de Louis XV, 5th edition, 2 volumes. Paris: Léopold Collin [orig. pub. posth. 1791]. Available at:

<https://babel.hathitrust.org/cgi/pt?id=njp.32101074209618;view=1up;seq=32/>. Accessed 10 October 2016.

Duclos, C. (1992) Les Confessions du Comte de ${ }^{\star \star \star}$, edited by L. Versini. Paris: Desjonquères [orig. pub. 1741-1742].

Duclos, C. (2005) Considérations sur les moeurs de ce siècle, edited by C. Dornier. Paris: Champion [orig. pub. 1751].

Durand, Y. (1971) Les fermiers généraux au XVIIIe siècle. Paris: Presses Universitaires de France.

Félix, J. (2011) Modèles, traditions, innovations: Le Peletier des Forts et la renaissance de la finance sous le règne de Louis XV. In: Dubet, A. and Luis, J.-P. (eds.) Les Financiers et la construction de l'État: France, Espagne (XVIle-XIXe siècle). Rennes: Presses Universitaires de Rennes, 125-54.

Godefroy, F. (1881) Dictionnaire de l'ancienne langue française et de tous ses dialects du IXè au XVè siècle. Paris: F. Vieweg. Available at: <http://gallica.bnf.fr/ark:/12148/bpt6k50634z/>. Accessed 16 July 2016.

Grosclaude, P. (1961) Malesherbes: Témoin et interprète de son temps. Paris: Fischbacher.

Guichard, C. (2012) Taste communities: The rise of the amateur in eighteenth-century Paris. Eighteenth-Century Studies, 45(4): 519-47.

Hamon, P. (1999) 'Messieurs des finances': Les grands officiers de finance dans la France de la Renaissance. Paris: Imprimerie nationale.

Helvétius, C.-A. (1991) Correspondance générale d'Helvétius, vol. 3: 1761-1774/Letters 465-720, edited by A. Drainard, M.-T. Inguenaud, J. Orsoni, D. Smith and P. Allan. Oxford: The Voltaire Foundation.

Hirschman, A.O. (1997) The Passions and the Interests: Political Arguments for Capitalism before Its Triumph. Princeton, NJ: Princeton University Press [orig. pub. 1977].

Kahan, M.B. (2010) Mouhy face à Jacquin: Le Financier comme contre-argument pour une autonomie du romancier. In: Herman, J., Peeters, K. and Pelckmans, P. (eds.) Le Chevalier de Mouhy: Bagarre et bigarrure. New York, NY: Rodopi, 197-208.

Kaiser, T.E. (1991) Money, despotism and public opinion in early eighteenth-century France: John Law and the debate on royal credit. Journal of Modern History, 63(1): 1-28.

Kettering, S. (1986) Patrons, Brokers, and Clients in Seventeenth-Century France. New York, NY: Oxford University Press.

Kwass, M. (2000) Privilege and the Politics of Taxation in Eighteenth-Century France: Liberté, égalité, fiscalité. Cambridge: Cambridge University Press.

Kwass, M. (2014) Contraband: Louis Mandrin and the Making of a Global Underground. Cambridge, MA: Harvard University Press.

de La Bruyère, J. (1975) Les Caractères, edited by A. Adam. Paris: Gallimard [orig. pub. 1688]. de La Mothe-Fénélon, F. de S. (1961) Examen de conscience sur les devoirs de la royauté: Mémoires 
pour le duc de Bourgogne [orig. pub. posth. 1734]. In: Guillemin, H. (ed.) Lettre à Louis XIV. Neuchâtel: Ides et calendes, 75-124.

de La Mothe-Fénélon, F. de S. (1995) Les Aventures de Télémaque, edited by J. Le Brun, Paris: Gallimard [orig. pub. 1699].

Lilti, A. (2015) The World of the Salons: Sociability and Worldliness in Eighteenth-Century Paris, translated by L.G. Cochrane. New York, NY: Oxford University Press [orig. pub. 2005].

Littré, É. (1872-1877) Dictionnaire de la langue française, 2nd ed. Paris: Hachette. Available at: <https://artfl-project.uchicago.edu/content/dictionnaires-dautrefois/>. Accessed 16 July 2016.

Magnot, F. (2010) Le don comme système dans Le Financier ou le rêve d'une redistribution des biens diffuse et anonyme. In: Herman, J., Peeters, K. and Pelckmans, P. (eds.) Le Chevalier de Mouhy: Bagarre et bigarrure. New York, NY: Rodopi, 209-22.

Martin, H.-J. (1984) La direction des lettres. In: Martin, H.-J. and Chartier, R. with Vivet, J.-P. (eds.) Histoire de l'édition française, vol. 2: Le livre triomphant 1660-1830. Paris: Promodis, 64-75.

Matthews, G.T. (1958) The Royal General Farms in Eighteenth-Century France. New York, NY: Columbia University Press.

Maza, S. (2003) The Myth of the French Bourgeoisie: An Essay on the Social Imaginary, 1750-1850. Cambridge, MA: Harvard University Press.

McCleod, J. (2011) Licensing Loyalty: Printers, Patrons, and the State in Early Modern France. University Park, PA: Pennsylvania State University Press.

Meister, P. (1956) Charles Duclos (1704-1772). Geneva: Droz.

Monselet, C. (1876) Les oubliés et les dédaignés: Figures de la fin du XVIIIe siècle, new definitive ed. Paris: Charpentier.

de Montesquieu, C.-L. (1979) De l'esprit des lois, edited by V. Goldschmidt, 2 vols. Paris: Flammarion [orig. pub. 1748].

de Montesquieu, C.-L. (1995) Lettres persanes, edited by L. Versini. Paris: Flammarion [orig. pub. 1721].

Mornet, D. (1910) Les enseignements des bibliothèques privées (1750-1780). Revue d'Histoire littéraire de la France, 17(3): 449-96.

de Mouhy, chevalier, C. de Fieux (1755) Le Financier, 2 vols. Amsterdam: J. Neaulme.

Murphy, A.E. (1997) John Law: Economic Theorist and Policy Maker. Oxford: Oxford University Press.

Murphy, A.E. (2005) John Law: Innovating Theorist and Policymaker. In: Goetzmann, W.N. and Rouwenhorst, K.G. (eds.) The Origins of Value: The Financial Innovations That Created Modern Capital Markets. New York, NY: Oxford University Press, 225-38.

Neal, L. (1993) The Rise of Financial Capitalism: International Capital Markets in the Age of Reason. Cambridge: Cambridge University Press.

Offer, A. (1997) Between the gift and the market: The economy of regard. Economic History Review, 50(3): 450-76.

Parsons, J. (2014) Making Money in Sixteenth-Century France: Currency, Culture, and the State. Ithaca, NY: Cornell University Press.

Peron, M. (1991) Théories prérévolutionnaires de l'impôt: Mirabeau, les Encyclopédistes et Adam Smith. In: État, finances et économie pendant la Révolution française: Colloque tenu à Bercy les 12, 13, 14 octobre 1789. Paris: Imprimerie nationale, 53-65.

Perrot, J.-C. (1984) Nouveautés: I'économie politique et ses livres. In: Martin, H.-J. and Chartier, R. with Vivet, J.-P. (eds.) Histoire de l'édition française, vol. 2: Le livre triomphant 1660-1830. Paris:

Promodis, 240-57.

Piketty, T. (2013) Le capital au XXIe siècle. Paris: Seuil.

Polanyi, K. (1944) The Great Transformation. New York, NY: Rinehart.

Quemada, B. with Pruvost, J. (eds.) (1998) Le Dictionnaire de l'Académie française et la lexicographie 
institutionnelle européenne, Actes du colloque international, 17, 18 et 19 novembre 1994. Paris: Honoré Champion.

Raunié, É. (ed.) (1882) Chansonnier historique du XVIIle siècle: Recueil de chansons, vaudevilles, sonnets, épigrammes, épitaphes et autres vers satiriques et historiques, Formés avec la Collection de Clairambault, de Maurepas et autres manuscrits inédits, vol. 7. Paris: A. Quantin.

Richelet, P. (1680) Dictionnaire françois, contenant les mots et les choses, plusieurs nouvelles remarques sur la langue françoise. Geneva: Jean Herman Widerhold. Available at: <http://gallica.bnf.fr/ark:/12148/bpt6k509323/>. Accessed 16 July 2016.

Rivara, A. (2010) Un écrivain caméléon, Chevalier inexistant ou figure 'd'auteur' hardie? Lecture et création chez le chevalier de Mouhy. In: Herman, J., Peeters, K. and Pelckmans, P. (eds.) Le Chevalier de Mouhy: Bagarre et bigarrure. New York, NY: Rodopi, 7-24.

Roche, D. (1984) La censure. In: Martin, H.-J. and Chartier, R. with Vivet, J.-P. (eds.) Histoire de l'édition française, vol. 2: Le livre triomphant 1660-1830. Paris: Promodis, 76-83.

Rogister, J. (1995) Louis XV and the Parlement of Paris, 1737-1755. New York, NY: Cambridge University Press.

Root, H.L. (1993) La construction de l'état moderne en Europe: Le cas de la France et de l'Angleterre. Paris: Presses Universitaires de France.

Sewell, W. (2010) The empire of fashion. Past and Present, 206(1): 81-120.

Shaw, E.P. (1955) The Chevalier de Mouhy's newsletter of 20 December 1752. Modern Language Notes, 70(2): 114-116.

Shoemaker, P.W. (2007) Powerful Connections: The Poetics of Patronage in the Age of Louis XIII. Newark, DE: University of Delaware Press.

Smith, J. (1996) The Culture of Merit: Nobility, Royal Service, and the Making of the Absolute Monarchy in France, 1600-1789. Ann Arbor, MI: University of Michigan Press.

Stewart, J.B. (2008) The Omen: How an obscure Breton trader gamed oversight weaknesses in the banking system. The New Yorker, 20 October: 54-65.

Turnovsky, G. (2010) The Literary Market: Authorship and Modernity in the Old Regime. Philadelphia, PA: University of Pennsylvania Press.

Vaillé, E. (1953) Histoire générale des postes françaises, vol. VI.i, La Ferme générale et le groupe Grimod-Thiroux (1738-1789). Paris: Presses Universitaires de France.

Vasseur, F. (2010) Comment j'ai liquidé le siècle. Paris: Équateurs.

Walter, E. (1984) Les auteurs et le champ littéraire. In: Martin, H.-J. and Chartier, R. with Vivet, J.-P. (eds.) Histoire de l'édition française, vol. 2: Le livre triomphant 1660-1830. Paris: Promodis, 38399.

Weil, F. (1986) L'Interdiction du roman et la librairie, 1728-1750. Paris: Aux amateurs de livres.

Weil, F. (1999) Livres interdits, livres persécutés, 1720-1770. Oxford: Voltaire Foundation.

White, E.N. (2004) From privatized to government administered tax collection: Tax farming in eighteenth-century France. Economic History Review, 57(4): 636-63.

Ziskin, R. (1999) The Place Vendôme: Architecture and Social Mobility in Eighteenth-Century Paris. New York, NY: Cambridge University Press. 